\title{
Disjecta membra, as profanidades de H. G. Cancela Disjecta membra: profanities by H. G. Cancela
}

Cláudia Capela

Universidade de Trás-os-Montes e Alto Douro (UTAD), Vila Real / Portugal Universidade de Évora (UÉVORA), Évora / Portugal claudiacapelaferreira@gmail.com https://orcid.org/0000-0001-7931-689X

Resumo: Este texto lê as narrativas de H. G. Cancela como um ritual antropofágico de apropriação e interdiscurso, e a escrita enquanto eterno rito de sedimentação e recomeço, paródia transgressiva, lugar da dúvida e do possível. Numa tessitura alegórica, o discurso desenha-se no âmbito da matéria ela mesma da palavra, da relação da mão que escreve consigo, com as outras, na ambivalência da literatura maiusculizada. Pervertendo-a e dominando-lhe o corpo sacro, o autor confronta-a no seu domínio. A escrita como parafilia macula e subverte: quem muito profana, sagra.

Palavras-chave: antropofagia; palavra; profano; H. G. Cancela.

Abstract: This text explores the discourse of H. G. Cancela as an anthropophagic writing ritual upon the notion of apropriation and interdiscourse. Writing seems to follow the notion of possible as a place for transgressive parody. Literature is never just a word, but a confrontation in its own body. Profanation of a so-called sacred body, writing may be a parafilic subversion intended to break literature's body down into pieces.

Keywords: anthropophagy; word; profane; H. G. Cancela. 
Quem quer que tenha atravessado a via crucis dos nazarenos da Semana Grande de Sevilha, ou quem quer que tenha sido amaldiçoado depois de recusar a mão à quiromância na Plaza de España, bem concebe Impunidade nesta cidade andaluza. Não se trata de uma perceção intelectual, nem de uma evidência nas orlas do espiritual, mas de uma oscilação entre a realidade e a representação; é o corpo. Na obra de $\mathrm{H}$. G. Cancela, os lugares falam, o espaço é inteiramente aceitável como se de uma personagem se tratasse. A estilização dos cenários aprofunda a narrativa, consolidando significados que, porém, não crestam nesse símbolo imediato. Precisemos: de Sevilha de Impunidade (2014) avançamos para a Roma do anfiteatro em As pessoas do drama (2017), e daí para os confrontos de Paris de 1968, na mais recente narrativa do autor, A noite das barricadas (2020). O traço comum é, justamente, esse cariz de interpretação cénica, enfim, performance de que os ambientes estão imbuídos. Destituir a prosa de H. G. Cancela do espaço ou da forma é destituir a narrativa de si mesma. Este apego, provisório, ao lugar, que enforma, dilata e simultaneamente contrai, ultrapassa o espaço em si e reequaciona-o enquanto sedimentação do mundo. Não é por acaso que tanto se escava, terraplana e reconstrói sobre a ruína, o esplendor da ruína. No mundo de Cancela, poderíamos arriscar, a ruína é pedra-de-toque. A história, ou o tempo, eis um nódulo nevrálgico desta poética. ${ }^{1}$

Afim às variações Goldberg, trata-se esta obra de um aglutinado efetivador de um espaço discursivo do qual resultam tais narrativas na sua independência. Eis a criação do mundo do autor. Experiência dele. O matricial Anunciação (1999), texto opressivo, graficamente violento - este traço aligeira-se ao longo da obra publicada até ao momento, a descrição física vai abrindo lugar à opressão psicológica, ou o aparato cénico transmuta-se para o simbólico - será paródia do nascimento para a morte de um Menino Jesus cristianizado à nascença, e indiciária de idêntica postura face à literatura. Trata-se de descontentamento pueril face às primícias? Denegação de texto, apenas possível se em recomeço? De qualquer forma, o profano move-se no mesmo fluido uterino do sagrado e qualquer profanação só o é por manutenção do seu oposto.

\footnotetext{
${ }^{1} \mathrm{O}$ espaço e esse tempo não nos permitem responder a todas as impressões de leitura da obra. De qualquer forma, também A Terra de Naumãn, narrativa de ficção científica/fantasia, fora deste escopo, se ocupa do tempo, da história e do ritual.
} 
Em Impunidade, um casal incestuoso, ou a mãe, repele a prole como efetivação de um resultado defeituoso de uma união ignominiosa, como se os filhos resultassem apenas aleijões e assim sujeitos a todo tipo de sorte mundana. São eles bastardos de criaturas divinas humanizadas cuja condição assume contornos de transgressão: aleijados literários fruto de incesto ou promiscuidade intertextual? Em As pessoas do drama, os papéis reanimam-se, dá-se palco ao incesto latente, a Antígona prenhe e cega a braços com um aperto de língua e assim de identidade, no papel de herdeira confusa quanto à sua genealogia. Herdeira de quê, de quem? Palavrões sagrados dessa literatura com maiúscula. A lei, a moral, a consciência individual e a sociedade patriarcal são motes de leitura deste foco narrativo. Por fim, em $A$ noite das barricadas, como que impetuosamente regredindo/ situando-se num tempo-espaço outro, predecessor ou análogo, evoca-se uma infância do narrador. Este narrador constante, o médico decepado, enquanto figura central das narrativas de Cancela, é-o e não o é, numa atualização de persona em processo de individuação e simultaneamente anulação, múltipla a cada ficção. O narrador será o mesmo e diverso, reinventando-se anti-herói a cada narrativa, sendo que a antecessora é anulada pela atual. Deste modo, a perda dos dedos terá sempre uma justificação diversa, e a infância, se houver lugar à recordação dela, é necessariamente divergente. Note-se a infância de Anunciação, em que o trauma sexual paira sobre a voz narrativa, ou a de De re rustica (2011), assinalada pela ambiguidade de filiação ${ }^{2}$ quer da personagem autodiegética, quer dos descendentes, ainda o incesto em Impunidade, o decalque dele e a evidência da violação em As pessoas do drama, e os efeitos da violência crua e desumanizante da guerra, da misoginia e misantropia perversa do progenitor sobre a infância do anti-herói de Cancela na última ficção. A devastação cínica dos indivíduos é o

\footnotetext{
2 A questão da filiação é um tópos relevantíssimo na tradição literária portuguesa, a par da ironia e da conceptualização da literatura como indagação paródica. De Almeida Garrett, nomeadamente em Viagens na minha terra, a Camilo Castelo Branco, em Amor de perdição, em que o amor é símbolo, mais do que de entendimento amoroso, de liberdade e insubmissão, desafio e resistência ao predecessor, ou ainda a Maria Velho da Costa, o mal de sangue, que se aceita ou declina a favor da fratria ou afinidade literária, pressupõe um extenso e profundo mote de estudo na alusão à patronímica e às relações metaliterárias.
} 
resultado de prévia vivência adversa; a vida é hostil às suas criaturas e nada parece revelar-se redentor. Assim, na sua última vida, o médico perde os dedos num atentado levado a cabo pelo pai contra a vida da sua esposa e do seu amante. As crianças são vítimas paralelas da violência impune dos pais, como já haviam sido as de Anunciação, violência essa presente no trauma que enforma e deforma a vida do médico, ou as de Impunidade, com o abandono e o desenlace trágico dos dois irmãos, ou, finalmente, as da última narrativa:

a bebé dir-se-ia prestes a começar a chorar. Não emitia um som. A boca escancarada, as gengivas expostas, a língua retraída. A garganta aberta e o peito esmagado numa mancha de sangue [...] eu dera conta de uma dor mais intensa na mão direita. Levantara-a. Estava desfeita (CANCELA, 2020, p. 195).

Em H. G. Cancela é, assim, forçoso ler o tempo como uma categoria fora dele, manipulável pela palavra tomada nova narrativa e gestante de simultaneidades ou caminhos paralelos, mesmo diante de um mínimo vislumbre diacrónico. Leríamos: o protagonista, se o tomarmos apenas como um mesmo não o sendo, experimenta-se simultaneamente em bolhas paralelas, sincrónicas, sobre um registo evolutivo. Como se de um mito se tratasse, esta obra sedimenta, mescla, pelo que declarar analepses ou prolepses seria erróneo, e, no entanto, os espaços são similares na sua também divergência, tal como as personagens e esse narrador constante, constantemente duplicável. O seu espaço não é fixo; como a obra não o é: ela resulta da sua permissibilidade, enquanto desfixamento, ao tempo, aos leitores, não estaticamente recetores, mas avatares dela. $\mathrm{O}$ narrador dribla possibilidades, conta-se, reconta-se, identifica-se nos entalhes negativos, mas furtam-se-lhe sempre os dedos, como se o real só se completasse na enunciação representativa dele. A identidade derrapa, constringe, acrescenta; a palavra distende. "E se" será o mote e a ficcionalidade, a encenação do real em relativização constante, num substrato individual de contrafação contínua. Assim, $A$ noite das barricadas será entrada para o mundo de um cético: Augusto é um pai celineano patente já em De re rustica (cf. aquele texto e o atual, "p[P]ode[s] tratar-me por a[A] ugusto" (CANCELA, 2011, p. 101) (CANCELA 2020, p. 63). De facto, não somente a crueza mineral 
da personagem, ou diga-se, da construção romanesca, evoca a obra de Louis-Ferdinand Céline; a misantropia das personagens, a revalidação da viagem enquanto símile de vida, e, entre outros, o facto de em $A$ noite das barricadas, a par do que sucede em Mort a credit, Augusto prevalecer como duplo e extensão do narrador, submetendo a esposa a violência sexual e física, sendo desses termos que as crianças, aparentemente, nascem, oferecem um substrato intertextual que, porém, não se limita a tal dialogismo, e valida a literatura como contrafação e homenagem, resistência e superação de paternidades, e reflexão metaliterária, como se a autoria fosse sempre uma forma de violência para com o texto e vice-versa.

Se a linguagem das duas narrativas iniciais indicia uma forma predominantemente psicanalítica, e a violência é crua e dirigida, as demais podem ler-se sob tendência mitográfica. A rarefação da matéria que, sem deixar de o ser, se faz representar de outra forma, como se o autor deixasse de escrever a cores para escrever a sépia, sem que isso seja limitação, mas aperfeiçoamento técnico. Nas personagens destas narrativas, pais e filhos, há um qualquer semblante russo, uma contraditória paixão de Rogójin, um Cristo parodiado, um Michkin do avesso - numa leitura de ambos como Janus -, de uma tragicidade sóbria; ou a contradição de um Eugénio Bazárov, que pode, optando-se por considerar possível a afeição de Augusto por Luísa (numa espécie de oposição a Love in the days of rage de Lawrence Ferlinghetti) e a recusa desta em segui-lo, replicar-se e explicar o niilismo destroçador da personagem.

$\mathrm{O}[\mathrm{s}]$ médico[s] de Cancela, mutilados, situam-se na raia, erráticos, o inacabado é a sua constância. As constantes viagens anunciam-no: vagueia-se ininterruptamente de lá para cá, repete-se o trajeto, como se o caminho distendesse o tempo, e a velocidade consentisse resistir no presente antes de um futuro infértil se impor, ou, até, surpreendê-lo como se se risse na face de um descuido da morte. E, no entanto, a vida é esse percurso insanamente repetível, à laia de uma viagem maior cujo caminho se desperdiça em função da obsessão do destino. As barricadas, também linguísticas, evocam a arbitrariedade do mundo e a [in]transponibilidade possível.

Se mapeássemos as constâncias arquetípicas deste espaço discursivo, a mãe ostentaria destaque. Aqui, qualquer mulher traz uma criança ao dependuro, seja reflexo da Senhora da Expectação, da 
Madona, ou decalque de Pietá, nesse logro da virgindade que os filhos lhe exigem. Lê-se, então, a Grande Mãe, a deusa minóica e ofídica, a reiteração contínua da síndrome de Hécate. Hipótese: esta mulher é literatura? E eis Maria do Céu (Anunciação), assim nomeada pelo primeiro cativo (não raro, os espaços são claustrofóbicos e a prisão ou as propriedades muradas situam as personagens em si mesmas), e assim em passivação, auscultada como anjo, que, subvertendo essa intenção circunstancial, a de anjo e de mãe, a desvirtua. As personagens repetem-se, autopovoam-se, renascem-se a cada narrativa reflexas, figuras. De facto, não obstante a autonomia e multiplicidade de cada texto, não apenas os temas de H. G. Cancela são reprise literária autocitada, mas as personagens elas mesmas, num processo lento, denso e distenso, formando um bloco coeso, obsessivo, obsediante. Há sempre um par primordial, aleijão, ${ }^{3}$ cujo diálogo se esgota ou perde na reprodução do gesto - porquê dizê-lo, se o gesto?, porque não dizê-lo, já que o gesto? Será Maria do Céu e o primeiro cativo, Lisa e o terceiro médico, Luísa e Augusto; na verdade, dir-se-iam romances contados pela dor e não pela aparente sinuosidade dócil dele, enfim, como a escrita de um livro. E se lemos tal discrepância como a agonia perante a afonia do indizível, também é possível ensaiar a impermeabilidade do sujeito individual perante o outro, ainda que sob a mesma sentença. Assim, sobrepõe-se um sentido de incomunicabilidade a que apenas o corpo poderá dar voz, na renúncia da palavra, excesso ou míngua, como se entre dois amantes se forjasse meramente uma linguagem traduzível mas não habitada, o que provirá de uma cisão cultural reafirmada no papel de género e que nestes textos exerce um substancial pendor sobre as ações das personagens, naquilo que as acomete da violência, por

\footnotetext{
${ }^{3}$ Uma breve nota contrastiva para o final de De re rustica, embora ambíguo quanto à noção de disputa entre pai e filho sobre a mesma mulher, bem como para a última obra, em que o espaço afetivo de um dos casais-espelho ou duplo sugere uma alternativa à incomunicabilidade, esta decorrente de qualquer falocentrismo culturalmente herdado, dobrando a noite como os versos de Ferlinghetti ou um qualquer filme italiano. Em termos simbólicos, prevê-se uma qualquer réstia de harmonia díspar em grau mínimo, ou, como o autor refere, quanto àquilo que apelida de desfasamento, uma "não coincidência constitutiva" (CANCELA, 2019, p. 38). De qualquer forma, inferindo-se das situações-decalque, nada é conclusivo.
} 
vezes lírica, da admoestação do sentimento (cf. "matar-te [...] casar contigo"(CANCELA, 2014, p. 65)).

Sublinha-se ainda a gravidez (Maria do Céu, rapariga, Lisa, Laura) o ciclo opressivo da gestação, a criança sem semblante salvífico e habitualmente entregue à sua solidão de coisa ou criatura una (relembre-se Laura, o irmão e Amir), uma perda ou luto, um Mefistófeles fáustico (presumíveis extensões declaradamente misóginas, misantrópicas do narrador: Amir, Victor, Augusto, o companheiro de Laura e o marido de Lisa, os quais chegam à fala com o narrador num semblante impositivo, humilhante, e, não raro, caraterizados como morte). Ainda a mulher tetraédrica, reflexo de irmã, mãe, filha, na repetição de Luísa, Lisa, Laura: mulher e alegoria da literatura, criação, alvo primordial do olhar primitivo desses homens, desejadas e diminuídas na mesma proporção. Finalmente, o [anti]Cristo ou a reverberação de homens que no caos configuram uma ordem não menos caótica, é dizer, a figura central destas narrativas. Paródica ou não, a figura tutela-se por uma solidão contínua, autoflagelatória, crística:

Levantei-me, limpei a terra da boca [...] Tinha a roupa rasgada, os dedos em sangue. A língua dura. [...] De repente tropecei, com a ponta aguçada de um ramo seco a roçar-me o peito e a resvalar em direcção à garganta [...] Ajoelhei-me junto da poça maior, debrucei-me e comecei a beber (CANCELA, 2014, p. 70).

A que dificilmente se resiste entender por via de uma sensibilidade violentada pela exigência de uma conduta masculinizante, no seu mais crestante símbolo viril, enquanto imposição. Os excessos penitentes, assim como a solidão, relevam decerto para a leitura simbólica enquanto tormenta da escrita.

A par da mulher-mãe, a infância é repetida, embora a criança denote a disparidade dúplice da promessa e do inalcançável, do futuro e do passado, como entrelace anulante. As crianças não vingam, amiúde se abandonam e refletem um estado que lhes é anterior e imediatamente posterior. A criança não inaugura senão perda, anulando a hipótese de um qualquer estado presente, como uma evidência da ligeireza da sua inocência. 
Amiúde, a mãe toma forma animalesca, instintiva - e eles não menos, em ânsia de sobrevida - é, portanto, uma Medeia em potência, uma Lâmia. A mãe encompassa com a morte. Em Impunidade, primeira narrativa do que poderia configurar uma trilogia de feições trágicas, lida como reatualização livre tendente ao melodrama ou até à farsa de uma maldição familiar à laia átrida, o regresso ao mesmo ovo exibe, mais do que uma paixão incestuosa de fundo perfeccionista, retorno corpóreo à mãe, que também o ato sexual preconiza, o retorno ao ventre como nascença e sepulcro. O narrador, de facto, alerta: "não há útero, creio, que me aceite de volta" (CANCELA, 1999, p. 33). Portanto, as petite mort são, sempre, um incesto e um suicídio. Simone Debout diria renascimento (apud BENAYOUN, 2019).

Ora, a figura do narrador de Anunciação, ginecologista e obstetra $^{4}$, pode ler-se como um José almejante e renitente, prefigurando esse dito pai (conflito geração/ tempo). O desejo, ou esse obscuro objeto dele, é do foro essencialmente mental, ${ }^{5}$ já que o corpo, por aparentes imposições traumáticas, responde ao fulgor do nascimento, da expulsão desse paraíso arcaico e afásico. Petite mort.

As personagens destes textos movem-se na penumbra consciente desse ciclo reprodutivo, sedimentação histórica, porventura antecipante de futuro, como se os nascituros obedecessem à premissa fixa de uma ordem no espaço arbitrário do mundo, de nascimento e danação automática. Pictoricamente, um eterno retorno firmado na figura demoníaca de Maestro dell' Avicenna que traga e pare, por assim dizer, ou pare e traga a humanidade. O semblante autofágico de Cronos é, igualmente, uma intuição passível de estruturação dos textos em leitura. A danação constante não deixa ela de ser rito, fruto de uma submissão masoquista à própria ideia da escrita. Porque se escreve? Porque se faz mundo, há de dizer-se, ainda que não se tenha nele pé.

\footnotetext{
${ }^{4}$ Instantâneo, eis o gesto do médico de Faust de Aleksander Sokurov, quando examina a vagina de uma paciente, tal como o próprio olho cinematográfico em close-up, Margarete (male gaze, cf. Laura Mulvey). Enfim, exame, ou Schaulust, na tradução literalíssima da palavra, da mulher.

5 Apesar do lugar da matéria, o corpo da mulher parece esporadicamente manipulável e o seu espaço psicológico algo elusivo, repetível, decorrente da focalização ou perceção do narrador; ou é relação sexual lacaniana, ou é paródia do fou e convulsivo.
} 
Sobrevivência é o mote, e, ambivalentemente, a tragédia. A mera subsistência por oposição à vida. Nesse sentido, o obstetra de Anunciação, que se não [se] escreve, se masturba, e que como tal se identifica organicamente, assumindo dois gestos convergentes em termos de expressão ou linguagem, coloca quer no discurso, quer na autoestimulação uma tónica de sustentação frustrada, gozo mecânico. A masturbação será sintoma de descontinuidade, réstia de autoerotismo e autocastração. Ou simples onanismo poético resultante em falhas identitárias. $\mathrm{O}$ prazer, decorrente da observação - o verbo olhar é crucial e merecia um estudo atento - prende-se com a figura da mãe, com uma vivência reprimida/simulação dela. Não é, porém, inviável o entendimento de um debutante de letras perante a literatura maisculizada e a aceitação da corte de outros iniciados. $\mathrm{O}$ ato de dar à luz, a impertinência da hesitação e o alívio (quanto isto tem de descrição do fazer literário e dele paródia) equivalem à impressão do grotesco, ou do abjeto, no limite do sexual:

O espectáculo da vulva dilatada e sangrenta humilha o mais forte. é difícil esquecer as fezes misturadas com a cabeça do feto [...] as pernas abertas de joelhos afastados deixavam a descoberto a vulva cada vez mais dilatada. esperei que estivesse próximo o momento da expulsão, saí para o quarto de banho, encostei-me à parede e fechei os olhos. concentrei-me na imagem da rapariga e fi-lo ali mesmo [...] mas foi ainda de luvas pegajosas que recebi a criança (CANCELA, 1999, p. 45).

Ou, no fim do livro: "segurei-o entre as mãos, agitou-se [...] a criança atravessou os vidros e foi desfazer-se no pátio [...] o esperma corria-me pelas pernas." (CANCELA, 1999, p. 157).

Jesus é cristianizado à nascença; não há salvação, nunca houve. As afinidades entre a reprodução e a morte, citando Eroticism, de Bataille (2012), dão conta do tabu como resposta à necessidade de banimento da violência do quotidiano e do facto de a vida ser um produto de decomposição da mesma. Transgredindo, a violência exala a sua presença perentoriamente sobre o campo do consciente. Ora, tal episódio, aliado à violência opressiva da reclusão de Céu, a par da hedionda morte de Laurinha de Impunidade, ou das inúmeras referências à violação nestas narrativas, entre outras situações, criam um substrato 
repulsivo e grotesco. Leia-se, da morte da criança: "Deitou-a no chão, segurou-a pelo pescoço e tapou-lhe a boca, para abafar os gritos, enquanto introduzia a tesoura e a sua mão se cobria de sangue. Quando ela o mordeu, ele agarrou-lhe a cabeça com ambas as mãos e bateu com ela contra o soalho" (CANCELA, 2014, p. 131).

Enquanto tema, no cinema, porque a linguagem de Cancela insinua um olhar cinematográfico que exigiria outro tipo de análise formal muito mais amplo do que apenas a perspetivação da representação da mulher como objeto, segundo Laura Mulvey, ou Gaylan Studlar por contraste, e com a qual os narradores jogam ${ }^{6}$ (Sade/ Masoch), o ensaio sobre o arquétipo feminino, também em relação ao masculino, é variadíssimo. Não vemos como ultrapassar um paralelo entre o autor e Lars von Trier pelo grafismo da violência, ou Catherine Breillat, pelo assunto. Como provocateur, o artista instiga a pergunta, embora nunca a faça, exime-se da resposta, submete à violência com uma pretensão reativa, ensaística. O grotesco burilado pelo cineasta e por Cancela - em diversos momentos e minuciosos detalhes, a par dos tabus e das transgressões, e aqui os fluidos corporais, saliva, sangue, sémen conjugam-se; sexo e violência, vida e morte são quase indiscerníveis, ou, antes o limite entre ambos é ténue -, como antítese, descontinuidade e heterogeneidade, tende a essa outrização do espaço comum; diríamos, uma imersão no extraordinário, evasão de uma mediania. Entramos, assim, na apetecível substância da profanidade, no barroco, na paródia, na crispação contra a neutralidade, no excesso dionisíaco. Em termos literários significa isto uma incisão no corpo dessa novíssima literatura portuguesa, conjugando a ambivalência, a ludicidade no tratamento do tempo, com a forma despojada, cínica, alegórica, tendente à sobriedade e acalmia, no espaço ou silêncio entre cada palavra, como quem se esforça por rasurar qualquer indício lírico na frase síncope, e perfaz do discurso e da linguagem o essencial. A palavra literária como garante

${ }^{6} \mathrm{O}$ olhar em plongée sobre a mulher, e esse plano de olho dito divino, um male gaze. Atente-se, porém, num dos discursos-cena em $A$ noite, quando o narrador, prestes a trocar de vestes, e que a par de outro discurso-cena de As pessoas merecia análise por contraste, adivinha essa outra, medindo "o mundo segundo os olhos dela" (CANCELA 2020, p. 34), para o renegar e subsistir numa falha. Há sempre um hiato dúplice, como os narradores de Cancela, lácero ou alimentício. 
de profanação da mesma no seu próprio território, interdito pela norma, como no corpo pela transgressão.

$\mathrm{O}$ grotesco será cair para trás. Sem sustentação. Ou no desconhecimento dela, na dúvida. Acontece amiúde com a leitura de certo tipo de textos roçando o limiar dos abismos. O abjeto, a incerteza, o ambíguo, ou o espaço onde se moldam e quebram os limites, e o sujeito é confrontado com o sem nome, o arcaico, esse incerto contido em God (2007) de Terence Koh, por exemplo: "Plaster, wood, paint, wax, Eros lube, artist's saliva, cum of the artist and others": o outros é que intriga. Se tomarmos a noção de literatura de Julia Kristeva enquanto versão do apocalipse enraizada na fragilidade das fronteiras de identidade (KRISTEVA, 1982, p. 207), bem como essoutra perspetiva da personagem pós-moderna de Ana Paula Arnaut, fragmentária, entrópica, facilmente lemos a galeria de personae de Cancela como criaturas fantasmais dismórficas insufladas pela palavra. Se não em crise, pelo menos resultantes do movimento errático de um corpo decepado: seja o médico, as crianças balbuciantes, seja a grávida que morde a língua como quem sucumbe ao prazer de uma lâmina, a atriz que adia a palavra e se faz regredir a um estado de dependência pré-linguística, ou a amante que nunca responde às perguntas que lhe são feitas, todas essas mulheres nessa mudez bergmaniana que tanto questiona o logocentrismo, como faz da logorreia lábil de terceiros um pretexto para [sobre]viver.

O abjeto será, aqui, uma constante refiguração da morte, o colapso da linguagem quando em face daquela (cf. Augusto duplicado no cadáver do irmão (A noite das barricadas) e, de resto, como não ler o seu discurso como desaparecimento e autotanatografia? $)^{7}$, ou o corpo de Laurinha na morgue (Impunidade), e não será por acaso a constante perceção paródica do narrador como figura crística avançando pelo Monte das Oliveiras, amiúde ferido e amputado. ${ }^{8}$ De língua, isto é, da perceção e organização de discurso diante da morte. O discurso de Augusto é violentíssimo e sugere a dispersão/duplicação do narrador-personagem,

\footnotetext{
${ }^{7}$ Cf. Derrida, Blanchot, Sontag, Butler.

${ }^{8} \mathrm{O}$ deambular será próprio da afasia face à irrepresentabilidade do todo, a tal impossibilidade das nuvens de Goethe, ou sequer do ínfimo, e de uma identidade tendente à sua perda por entre a crescente velocidade espaciotemporal e inutilidade do movimento.
} 
enfim capaz de dar forma à abjeção nesse desdobramento. ${ }^{9} \mathrm{O}$ terror deleitoso (Burke, 1990) da morte, de que a oscilação entre aquela e a vida nas pulsões libidinais ou parafílicas (o termo não é irrepreensível mas terá de bastar) é exemplo, traduzida no mote de Der Tod und das Mädchen ${ }^{10} \mathrm{e}$ que, de certo modo, se filtra ante a figura gótica agonizante de Augusto, invade o paradoxal, na obscuridade da atração e do horror, num céu e inferno de Blake, numa exaltação boschiana.

Esta súbita erupção do Real (Lacan), como se nos afigura segundo Kristeva (abjeto), é fundamental como organização de amplitude para representação do possivel, termo reiterado nos escritos ensaísticos de Cancela, e que fará convergir a literatura enquanto palavra para a vida, e o mutismo para a ausência dela. ${ }^{11} \mathrm{O}$ desejo traduz frémito, a debilidade, termo. Sob o rigor actancial de Perséfone, que em $A$ noite das barricadas é vagamente sugerido pela figura de Helena - leia-se a iteração de Helena mítica como eidolon, simulacro/ausência, desejo/coação, duplicação de/em Luísa - este trágico equilíbrio parece ganhar sentido na obra em leitura. A abjeção pode ser catártica? $\mathrm{O} e u$ em presença da morte, numa experiência do corpo como cadáver, presença simultânea ausência, membro desmembro, des/corporização, traduz o estranhamento, afeta o sujeito e o objeto, dificulta o ego e a identificação junto à barreira tão limítrofe vida/morte. O medo/desejo de dissolução do $e u$, não raro em duplo (ou em multitudes), enfrenta assim essa velha familiaridade que corrói o simbólico e o corpo como discurso, confrontando-o nos limites do seu significado, logo, o discurso afunda-se no colapso do sentido: “«Já uma vez me vi morto» [...] não fora o irmão que ele vira no caixão, mas ele mesmo [...] Correra para o corpo e gritara-lhe que saísse dali. Atirara-se sobre o caixão, tentando despertar o cadáver [...] Demorara até que parasse de gritar" (CANCELA, 2020, p. 105).

Deste modo, não deixa de se ler o discurso libidinoso/ o sexo como modo de expressão, a par do que, segundo Robert Benayoun,

\footnotetext{
9 Talvez possamos ler este(s) texto(s) como uma aprendizagem da morte, o que será dizer da vida. Ensaia-se aqui a morte, embora, segundo Bauman (2008), nem esta nem a outra se aprendam.

10 Cf. Claudius, Schubert, Grien, Dürer, Millais, Munch, Schiele, Plath, Abramovic (...).

11 Mais do que vida, reside na palavra como biografia ou como história o tópos de reunião dos improváveis, audição da versão paralela (narrador, pai e Helena); paradoxalmente, é nela ainda a viabilização do logro, o abrigo e cisão do muro.
} 
os surrealistas terão inaugurado. De facto, em toda a sorte de fetiches da obra - os objetos de desejo, o voyeurismo, o comportamento sadomasoquista - perpassa a noção de transgressão, restituindo um estado, enfim, de isenção ou escusa que permita gozar o corpo-discurso sem restrição. Trata-se de, mais do que consumir o corpo interdito, subverter o sacro. Bataille, em Literatura e o mal (2012), acusa já a regra como reveladora de uma felicidade possível quando transgredida. $\mathrm{O}$ episódio quase burlesco de nascimento-orgasmo é comparável à antropofagia, que na obra em questão assume contornos metalinguísticos, como se a arte fosse esse abocanhar de segmentos literários, musicais, cinematográficos, plásticos, e qualquer discurso, um interdiscurso; no caso, intercourse. Uma metáfora, se não onírica, pelo menos poética, uma intuição. A parafilia é equiparável à deglutição do cadáver pelas tribos amazónicas: rito sagrado, crime ou pecado. Perpetue-se entre culturas: Isto é o meu corpo que será entregue por vós (cf. Missal romano). Mitos cosmogónicos, vingança, ritual fúnebre. $\mathrm{Na}$ comunidade Yanomame, as cinzas dos mortos seriam ingeridas com um mingau de banana, perpetuando o espírito do falecido. Terá tanto de sórdido como de poético. Outras tribos praticariam tal ato como preservação do cadáver: tornar-se-iam, a dois tempos, portadores de vida e de morte, túmulo e perpetuação. Se pensarmos a arte como antropofagia, profanidade, portamos em nós o mundo desde o primeiro traço do primeiro auroque das margens do Côa. E estamos sempre prenhes, cheios, divinos. Sustenta.

Joga, este labor palimpséstico de Cancela, na amplitude do profano. Do incesto, transgressivo, afinidade literária, da herança à intertextualidade, da autoria à receção, da escavação do discurso, do prazer mastigável do texto; tanto como a violência perene do mundo, evoca-se a substância líquida da linguagem, indaga-se o espaço teórico literário. Sobre a categoria do reprovável, dos tabus a recitar, formaliza-se a transgressão na forma do corpo textual. Disjecta member, tessitura, tudo nos fala.

Em Missa in albis (1988), de Maria Velho da Costa, persiste um pendor auditivo euforizante, a escuta como sinal de comunhão. Repete-se amiúde estás a ouvir, ouves?, tudo nos fala, numa sinalização intertextual, metalinguística e até, enfim, fática, embora comunicação seja um termo precário no contexto literário. Na obra em estudo, o abjeto poderá reverter para semelhante aliciamento e interpelação. Se o texto 
obedecerá ou não a uma decifração desconstrutiva, ou a uma resposta na iminência da leitura como sedução, a verdade é que mesmo comendo os gomos, no final resta nada, nem um qualquer bolbo ou núcleo. Mas, entretanto, o fruto foi-se comendo. Seja como for, a literatura convoca esse espaço de ressonância determinado pelo desajuste e pela vivência pessoal que deslocam o sentido de autoria, termo abordado intensamente no domínio do estudos literários.

$\mathrm{Na}$ escrita palimpséstica de Cancela, e embora nos primeiros livros a leitura psicanalítica seja apetecível, a verdade é que a progressão aponta num aperfeiçoamento do tratamento da linguagem e na rarefação na formalização do arquétipo, diga-se: numa mitificação ou simbolização tendente ao velamento que enriquece e abre o texto à exploração fruidora. Passa-se, portanto, da psicologia para a matéria dela, o que a suplanta e eleva a obra. O texto torna-se gradualmente liberto de um fito direcional inflexível raiado de artificialismo, para a indiferença aparente quanto à inteligibilidade das cenas, desprendendo-se do cárcere da palavra, naturalizando-a: a linguagem expande e força à perceção além gráfica. Literatura. De facto, ao longo das obras, H. G. Cancela parece afastar-se gradualmente da expressão fatídica de reverência edipiana a essa literatura maiusculizada enquanto campo de manobras, como palavra, essa palavra dita fundadora, autoral, hierárquica.

O discurso bíblico, os discursos clássicos, trágicos, na revisitação de Antígona, Édipo, a figura de Cronos, as referências, a autocitação assentam numa estrutura esférica interdiscursiva da literatura como antropofagia, em que o discurso e o corpo nada objetam à transgressão, pois que a extensão do limite é a criação do mundo romanesco e ensaístico possível. Nesse sentido, a linguagem, como escrita parafílica, profanação sacra, é a da míngua de um eventual excesso descritivo, contenção mítica, do esvaziamento tendencialmente lírico sem contemplações, inserida a narração numa presentificação do transato como espaço ocupável e revisitável, o que permite a duplicação de personagem, reiterando a cisão identitária. Por outro lado, a personagem alegórica serve de títere de reflexão sem prejuízo do seu escopo romanesco e autónomo. 
A autoficção, ${ }^{12}$ à falta de termo mais claro, enquanto escrita e simulacro de self, mais do que autodistorção narrativa, ou alteridade performática, reflete a identidade em fluída manufatura - cf. os espelhos, as superfícies vítricas, os duplos, a materialidade lúdica da narrativa - disfarçando dionisicamente a mão que [se] [des]escreve. $\mathrm{O} / \mathrm{s}$ narrador/es da obra em causa, numa pretensão de familiaridade com os leitores, constroem subliminarmente uma ID autoral com que aqueles se confortam numa simulação de proximidade inexistente, na repetição de uma caraterização consistente daquele[s] que narra[m]. Neste jogo, o conceito biografista e autoral prevalece como mockery num universo essencialmente estético essencial para a formulação de um pensamento, como obra voltada ao outro. Os assim descritos romances (pacto ficcional inabalável, apesar de maleável) citados, que o serão, ultrapassam, não só pelo mínimo facto de se constituírem na primeira pessoa, tal estrita definição. A autoficcionalidade (espelho da velha instabilidade ontológica contemporânea) daí decorrente, como obra que se origina e simultaneamente os recetores-avatares dela, bem como a figura autoral - portanto, num exercício inverso ao costumeiro (especialmente hoje, na doentia exploração da figura autoral por oposição ao texto), denegada e consubstanciada na própria obra e dela, com ela, nascida, é aqui igualmente técnica de fuga, evasiva, história de um self escrita pelo self. A autoficção é a expressão do sujeito de enunciação ele mesmo, entidade fictícia, ser de linguagem, portanto, e não necessariamente daquele a que chamamos autor e assina estes textos, sem que, porém, deles se exima: este processo terá algo de intencional. A pretensa anulação deste a favor de uma figura-voz constitutiva de si mesma e da tessitura em devir é um ato submisso-libertador do fenómeno em estudo: age disfuncionalmente, narcísico e crístico num quadrante irónico da linguagem, do eu e não eu. Considere-se Frank e a ridicularização irónica do in/finito, a noção de self como assunção linguística de Fichte, ou Selbstschöpfung, Selbstvernichtung, Selbstbeschränkung de Schlegel, atendendo a De Man (1997).

Se alegoria, poderíamos ler: a mãe, literatura; a propriedade, constructo histórico e obra; o pai, influência/herança; arqueologia, leitura. Mas é igualmente carne e sangue humanos, e no que em nós

\footnotetext{
12 Termo genérico, precário, ante as teorias de Doubrovsky (1977), Groensteen (2007), Colonna (2007), Charpentier (2006), Derrida (1982), Schmitt, Summa-Knoop (2017).
} 
há de inumano como o tempo, e de transcendente como outra coisa qualquer; ensaio de pseudobiografias discursivas (o possível é ser tudo simultaneamente) ou partenogénese, à semelhança daqueles românticos feitos no entalhe da escrita, presidindo à sua des/construção identitária como demiurgos de si mesmos, discursivamente. Desta forma, essa mão decepada, plasmada na economia de um nome abreviado e outrado na capa, faz-se acompanhar por outras, conscientes do hiato que, porém, permanece entre os dedos - não raro, erro, excesso ou profanação: "profanação da própria autoridade do autor", comenta, afinal, Cancela (CANCELA, 2019, p. 82). Esta deturpação denega ou constitui? Sobre um texto, quantos outros são válidos? Não admira que Helena se estremunhe com a luz do quarto, raramente se vê mais do que para dentro e, nessa medida, cada texto é sempre dúplice, exibicionismo-voyeurismo. A ficção, qualquer texto, nasce do ato de escrita como desbravamento e ocultação. Ninguém se quer ver inteiro na palavra, um leitor procura esconder-se tendencialmente no que diz ver do autor, este oferece multiplicidades. Nenhuma parte quer o ónus. Se a morte é esquecimento de si em outrem, a leitura será "aprender a não ver" (CANCELA, 2020, p. 225), absorver, deglutir, tornar o hiato comestível, saturado da desfiguração que perpetua a palavra para lá do para lá. A noção de antropofagia lê-se na criação e apreciação enquanto assimilação de outridade ou, pelo menos, espelho e, assim, autofagia. Se Augusto, indivíduo, história, obra, encerra um qualquer substrato similar a uma alma, no entendimento que dela temos como ID, raiz, particularidade, e que, a par de outras subjetividades, resiste à denominação, talvez a sua perceção por parte dos leitores seja possível por via da emoção estética, de uma atenção fora do domínio do primeiro olhar, como se diante de Cnossos e ainda assim sem fio. Esse fio não fio não seria totalmente Ariadne, nem o palácio inteiramente Minos, e não salvaria ele mesmo do Minotauro.

A noção do eu como posse e destituição de si é o que encontramos em figuras jorrantes como Amir ou Victor, o qual, a par de um Cossery posterior, escreve e não verbaliza. Esse afeto-cisão entre dois mundos, ocidente e oriente, que Sevilha, como outras cidades europeias hoje tão eficazmente pintam, categoriza uma forma de violência que sempre se perpetua ela mesma nesta poética, e experimenta as línguas como corruptela e permanência, a cultura ou a civilização como choque e opressão, afinal realidade histórica nunca desvirtuada dessa alimentação 
póstuma, como evoca a deglutição do Bispo Sardinha lembrada por Oswald de Andrade e a sua antropofagia como cosmovisão. O que resiste e o que acaba delegado para a categoria do olvidável, recuperável por uma narrativa posterior via arqueologia ou tradição, eis a natureza mais ou menos sombria ou luzidia do real. Mas este real é-o, ou apenas experimentado enviesadamente? Digamos a propriedade, a posse, de que tanto se fala nestes textos desde, pelo menos De re rustica, a fronteira, a terra, é possível possuir verdadeiramente alguma coisa, alguém, um pensamento, um sentimento, uma obra, uma identidade, uma língua? Neste caso último, será, antes, a língua que possui. Lisa, Laura, Laurinha parecem impossibilitadas de alguma forma de tomar a palavra na boca. Amiúde bebem, mas não comem, personagens que são, a palavra ali é tão mastigável como uma língua morta. Fluido, sopro. Têm noção da superficialidade do nome por oposição à coisa, e talvez saibam ou intuam que não se toma a coisa pelo nome com que se lhe refere. A palavra prevê e simultaneamente incapacita, verdadeira barricada, não chega a formalizar senão ficção (cf., por exemplo, Laura: "O trânsito entre uma língua e outra tornava claro quanto qualquer delas era precária" (CANCELA, 2017, p. 166), ou "Ao falar, sentia-se a personagem de um filme estrangeiro dobrado para italiano por maus actores, servidos por uma tradução errónea" (Ibidem, p. 190).

Ora, isto pode constituir um problema, constituirá um problema para os narradores de Cancela? Para Augusto parece ter sido. O facto de se escrever sempre na ruína da palavra face ao mundo. De se fazer representar o mundo por algo tão intrinsecamente imastigável como as bolas de pão demolhado no leite de Laurinha. Laura não fala porque não quer, segundo a mãe, e não o faz por impossibilidade afeta à sua voz tida como género feminino (lembremos essas Elisabeth e Alma) ou não fala justamente para não se deixar ludibriar pela esfera linguística do tempo? Laura, no limite da afonia, não tem capacidade de fazer representar um mundo, vê-o ainda nas margens do linguajável "Introduzia na boca o indicador direito e contornava-a pelo interior, evitando os tecidos moles, à procura do esmalte dos dentes e da consistência óssea dos maxilares" (CANCELA, 2014, p. 31), arcaico, não o organiza, não o submete, mas também não se lhe submete. É toda mito, ou texto mal acabado, e como mito se dissolve às mãos dessoutra criatura nos limites de qualquer coisa que não se entende senão por ação nefasta de um atavismo celular. O eu pode ser violento como a 
cultura, a civilização, a nacionalidade. Portanto, possuir uma língua, apesar de excrescência ou de míngua, ainda será pertencer-se a algum pervertido domínio que não ostracize o sujeito de si mesmo? Mas não seremos desejavelmente bilingues, nesse entalhe, hibridação, fronteira amovível? A língua muda o sujeito ou o sujeito muda a língua? Diga-se língua, diga-se mundo. Este fosso que aqui se representa, e em Cancela as personagens representam realmente sempre, no domínio do gesto delimitador desse dramatismo, da performance do $e u$ perante o $t u$, o outro, é uma materialização de um passado e de um futuro que se toma como regra e que quando se olha, já passou. Quando Tutmés, o quarto, subiu ao trono, a esfinge era já uma ruína.

A ruína pode tanto referir-se ao tempo e à noção clara dele, como a personagem de Lispector (A paixão segundo G. H.) do alto do minarete-quarto, arrasando o mundo sob as areias e simultaneamente revoltando-lhas, e poderá amplificar um registo sonoro ou legível do outro em nós, de um passado que nos percorre, e do qual o sujeito se evade não talvez o suficiente para se constituir uno e univocal. $O$ mesmo ocorre na arte. Diz que não existe novidade desde o discurso salomónico, e no entanto tudo é novo. A ruína é de onde se erigem variações do discurso de Salomão, de Sulamita, da poesia de Safo. Quando Cancela evoca Céline ou uma linhagem literária indagadora, não evoca a literatura toda (Kristeva (1982) discordaria, talvez eu tenda a discordar-me), mas evoca um estado de espírito que lhe é subserviente e que a mantém, uma esfera arcaica, um qualquer indizível que se mostra mas que mesmo escrevendo nunca se diz. Pode ser desespero, pode ser ceticismo, cinismo, niilismo. Até pode ser o reverso. E o sublime.

Permanece a dúvida, se havemos de indagar a catarse nalgum canto obscuro, ou se está aí numa palavra interdita e apenas percetível como intuição daquilo que pobremente veste.

\section{Referências}

BATAILLE, G. Eroticism. London: Penguin, 2012.

BATAILLE, G. Literature and evil. London: Penguin, 2012. 
BENAYOUN, R. Érotique du surréalism. Paris: Pauvert/FeniXX, 2019. e.Pub

BAUMAN, Z. Liquid love. Malden: Polity Press, 2008.

BURKE, E. A philosophical enquiry into the origin of our ideas of the sublime and the beautiful. Oxford: University Press, 1990.

CANCELA, H. G. Anunciação. Porto: Edições Afrontamento, 1999.

CANCELA, H. G. De Re Rustica. Porto: Edições Afrontamento, 2011.

CANCELA, H. G. Impunidade. Lisboa: Relógio D’ Água, 2014.

CANCELA, H. G. O exercício da violência. A arte enquanto tempo. Lajes do Pico: Companhia das Ilhas, 2014.

CANCELA, H. G. As pessoas do drama. Lisboa: Relógio D’ Água, 2017.

CANCELA, H. G. A noite das barricadas. Lisboa: Relógio D’ Água, 2020.

CÉLINE, L.F. Death on credit. Death on the instalmment plan. Richmond: Alma Books, 2009.

COLONNA, V. Autofiction \& autres mythomanies littéraires. Auch: Tristram, 2007.

DE MAN, P. The Rhetoric of Romanticism. New York: Columbia University Press, 1983.

DE MAN, P. Aesthetic Ideology. Minneapolis: University of Minneapolis Press, 1997.

DERRIDA, J. The Ear of the other. Otobiography, Transference, Translation. New York: Schocken Books, 1982.

CHARPENTIER, I. "Quelque part entre la littérature, la sociologie et l'histoire..." Contextes [En ligne]. v. 74, 2006. Disponível em: http:// journals.openedition.org/contextes/74. Acesso em: 17 mar 2021. 
DI SUMMA-KNOOP, L. Critical autobiography: a new genre?, Journal of Aesthetics \& Culture, Volume 9, 2017.

DOUBROVSKY, S. Fils. Paris: Éditions Galilée, 1977.

GROENSTEEN, T. The system of comics. Jackson: University Press of Mississipi, 2007.

KRISTEVA, J. Powers of horror. An essay on abjection. New York: Columbia University Press, 1982.

LISPECTOR, C. A Paixão de G. H. Lisboa: Relógio D’ Água, 2013.

KOH, T., God. [Sculpture; Plaster, wood, paint, wax, Eros lube, artist's saliva, cum of the artist and others], 2007, (Städelsches Kunstinstitut Collection, Frankfurt am Main). 